\title{
Deep bed filter as pre-treatment to stormwater
}

\author{
M.A.H. Johir, S. Vigneswaran*, J. Kandasamy \\ Faculty of Engineering and IT, University of Technology, Sydney, P.O. Box 123, Broadway, NSW 2007, Australia \\ Tel.+61 (2) 95142641; Fax+61 (2) 95142633; email: s.vigneswaran@uts.edu.au)
}

Received 24 April 2009; Accepted in revised from 1 October 2009

\begin{abstract}
AB S T R AC T
This paper presents the results of experiments on the application of dual media and single media deep bed filters as pre-treatments to stormwater. In-line flocculation-filtration experiments were conducted with dual and single media filter. The single filter media $(80 \mathrm{~cm})$ consisted of either anthracite or sand, and the dual media filter consisted of sand $(40 \mathrm{~cm}$ at the bottom) and anthracite $(40 \mathrm{~cm}$ on top). Filtration velocities of $5 \mathrm{~m} / \mathrm{h}, 10 \mathrm{~m} / \mathrm{h}$ and $15 \mathrm{~m} / \mathrm{h}$ were examined. The removal efficiency for turbidity, suspended solids and TOC was found to be $95 \%, 99 \%$ and $30-45 \%$ respectively at a flocculant dose of $\mathrm{FeCl}_{3}$ of $15 \mathrm{mg} / \mathrm{L}$. The anthracite filter media showed a lower headloss development $\left(26 \mathrm{~cm}\right.$, operated at $5 \mathrm{~m} / \mathrm{h}$ filtration velocity with $\mathrm{FeCl}_{3}$ dose of $\left.5 \mathrm{mg} / \mathrm{L}\right)$. The removal efficiency for nitrogen was lower than phosphorus which was relatively good (up to $50 \%$ ). The removal efficiency for heavy metals such as $\mathrm{Cd}, \mathrm{Pb}, \mathrm{Cr}$ and $\mathrm{Ni}$ was found to be very low for all tested filtration systems because concentrations of these metals in the influent were also low. This filter can be used as a pretreatment to a membrane filter as the modified fouling index was reduced from $750 \mathrm{~s} / \mathrm{L}^{2}$ (for stormwater) to $15 \mathrm{~s} / \mathrm{L}^{2}$ (for filtered effluent). Detailed submerged membrane filter experiments conducted with pre-treated water showed that the membrane filter can be successfully be used as post-treatment to in-line flocculant-filter at a sustainable flux of $10 \mathrm{~L} / \mathrm{m}^{2} . \mathrm{h}$ to remove the remaining solids and pathogens. An increase of air scouring in the membrane unit decreased the pressure development although it did not have any effect on increasing the critical flux beyond $10 \mathrm{~L} / \mathrm{m}^{2} . \mathrm{h}$.
\end{abstract}

Keywords: Deep bed filter; In-line flocculation; Hollow fibre membrane; MFI

\section{Introduction}

Stormwater runoff is a main source of pollution flowing into waterways. The chemical characteristics of stormwater are dependent on the nature of surfaces such as roads, roofs etc. [1]. Structural best management practices (BMPs) such as filter strips and swales; infiltration systems (soakaways, infiltration trenches and infiltration basins); storage facilities (detention basins, retention ponds, lagoons, or sustainable urban drainage systems (SUDs) are widely used as treatment of stormwater to

\footnotetext{
* Corresponding author.
}

reduce the urban runoff peak flows as well as the amount of stormwater based pollutants entering the receiving water [1]. Studies have shown that a large number of constituents, both organic and inorganic, may be present in stormwater [1], both in their dissolved and colloidal forms and associated with particles. Such discharges of urban stormwater may cause numerous adverse effects including the export of heavy metals, organic compounds and pathogens to the receiving waters [2].

Filtration is one of the basic water treatment processes and it is becoming popular in wastewater treatment, especially in tertiary treatment [3]. Deep bed filtration is an effective process in removing particles of various nature 
and sizes that are present in water and wastewater. Rapid filtration finds its greatest application in the clarification of dilute suspensions (less than $500 \mathrm{mR} / \mathrm{l}$ ) of particles ranging in size from about 0.1 to about $50 \mu \mathrm{m}$ [4].

The use of membrane filtration as post treatment to contact flocculation filtration will help to remove pathogens and suspended solids. Submerged membrane reactor will have an additional advantage of lower energy requirement. The key features of submerged membranes are the removal of the permeate by suction (to avoid pressurising the membrane reactor) and the use of air bubbling as a primary fluid mechanical method to control deposition and fouling [5]. The membranes with the submerged systems are either hollow fibres, aligned vertically or horizontally, or flat plates aligned vertically.

In this study the effectiveness of in-line flocculationfiltration was investigated as pre-treatment to stormwater. The efficiency of the pre-treatment was studied in terms of solids, organic matter, nutrients and heavy matter removal in addition to pressure drop across the filter bed. A second set of experiments were conducted with hollow fibre membrane as a post treatment to deep bed filtration.

\section{Experimental}

The stormwater collected from a stormwater channel at Carlton, in Kogarah, Sydney had physical and chemical characteristics listed in Table 1.

\subsection{Deep bed filtration}

The experimental set-up is shown in Fig. 1. Short term ( $5 \mathrm{~h}$ ) in-line flocculation followed by deep bed filtration experiments were carried out using transparent acrylic filter columns. The internal diameter and length of the filter columns were $4.50 \mathrm{~cm}$ and $120 \mathrm{~cm}$, respectively. The columns were filled with filter media (anthracite and/or sand) up to a depth of $80 \mathrm{~cm}$. The anthracite and sand used in this study were obtained from James Cumming \& Sons $\mathrm{P} / \mathrm{L}$ and Riversands $\mathrm{P} / \mathrm{L}$ respectively and their properties are given in Table 2 . These filters were operated at filtration velocities of 5,10 and $15 \mathrm{~m} / \mathrm{h}$. The flocculant used was $\mathrm{FeCl}_{3}$ at doses of 5, 10 and $15 \mathrm{mg} / \mathrm{l}$. Down-flow filtration was employed and the effluent samples were collected for analysis from the outlet at the bottom of the column.

\subsection{Modified fouling index (MFI) experimental setup}

The pre-treatment efficiency was assessed in-terms of modified fouling index (MFI). We used the modified fouling index (MFI) established by Schipper and Verdouw et al. $[6,7]$ to evaluate the efficiency of pre-treatment in reducing the fouling of membranes when membrane systems used post treatment. The MFI experimental set-up is shown in Fig. 2. In each experiment new membranes (with a diameter of $47 \mathrm{~mm}$ and pore size of $0.45 \mu \mathrm{m}$ for
Table 1

Characteristics of stormwater during the study period

\begin{tabular}{|c|c|}
\hline Parameter & Value \\
\hline \multicolumn{2}{|l|}{ Nutrients } \\
\hline Total nitrogen, mg/L N & $0.39-8.4$ \\
\hline Nitrate, $\mathrm{mg} / \mathrm{L} \mathrm{N}$ & $0.38-7.9$ \\
\hline Nitrite, mg/L N & $0.069-0.97$ \\
\hline Ammonia, mg/L N & $0.4-1.15$ \\
\hline Total phosphorous, mg/L P & $0.021-0.36$ \\
\hline Orthophosphate, mg/L P & $0.02-0.026$ \\
\hline \multicolumn{2}{|l|}{ Traditional (physical and chemical) } \\
\hline $\mathrm{pH}$ & $6.68-7.28$ \\
\hline TOC, mg/L & $3.48-9.52$ \\
\hline $\mathrm{COD}, \mathrm{mg} / \mathrm{L}$ & $30-65$ \\
\hline Turbidity, NTU & $2.5-40$ \\
\hline Total suspended solids, mg/L & 24-35 \\
\hline Conductivity (EC), dS/m & $0.13-0.97$ \\
\hline True colour, PtCo & $29-270$ \\
\hline Bicarbonate, $\mathrm{mg} / \mathrm{L} \mathrm{CaCO}_{3}$ equivalent & 30-95 \\
\hline Total dissolved salts, mg/L & $90-660$ \\
\hline Carbonate, mg/L $\mathrm{CaCO}_{3}$ equivalent & $0-21$ \\
\hline Water hardness, mg/L $\mathrm{CaCO}_{3}$ equivalent & 22-135 \\
\hline \multicolumn{2}{|l|}{ Bacteriological } \\
\hline Total coliforms, cfu/100 ml & $150-28000$ \\
\hline Faecal coliforms, cfu/100 ml & $10-500$ \\
\hline \multicolumn{2}{|l|}{ Dissolved salts } \\
\hline Potassium, mg/L & $0.5-7.9$ \\
\hline Sodium, mg/L & $6.4-126.0$ \\
\hline Calcium, mg/L & $7.2-32.2$ \\
\hline Magnesium, mg/L & $1.0-13.3$ \\
\hline Sodium absorption ratio, mg/L & $1.0-4.7$ \\
\hline Chloride, $\mathrm{mg} / \mathrm{L}$ & $17-176.4$ \\
\hline Sulphate, $\mathrm{mg} / \mathrm{L} \mathrm{SO}_{4}^{2-}$ & $3.6-86.2$ \\
\hline Chloride/sulphate ratio & $1.4-4.7$ \\
\hline \multicolumn{2}{|l|}{ Metals } \\
\hline Aluminium, mg/L & $0.04-0.16$ \\
\hline Arsenic, mg/L & 0.001 \\
\hline Cadmium, mg/L & 0.001 \\
\hline Chromium, mg/L & 0.002 \\
\hline Copper, mg/L & $0.029-0.049$ \\
\hline Iron, mg/L & $0.53-2.55$ \\
\hline Manganese, mg/L & $0.28-0.375$ \\
\hline Nickel, mg/L & $0.002-0.10$ \\
\hline Lead, mg/L & $0.019-0.022$ \\
\hline Selenium, mg/L & $0-0.004$ \\
\hline Zinc, mg/L & $0.321-0.382$ \\
\hline
\end{tabular}

most of the experiments and with a 17.5 KD UF membrane for the remainder of the experiments) were used 


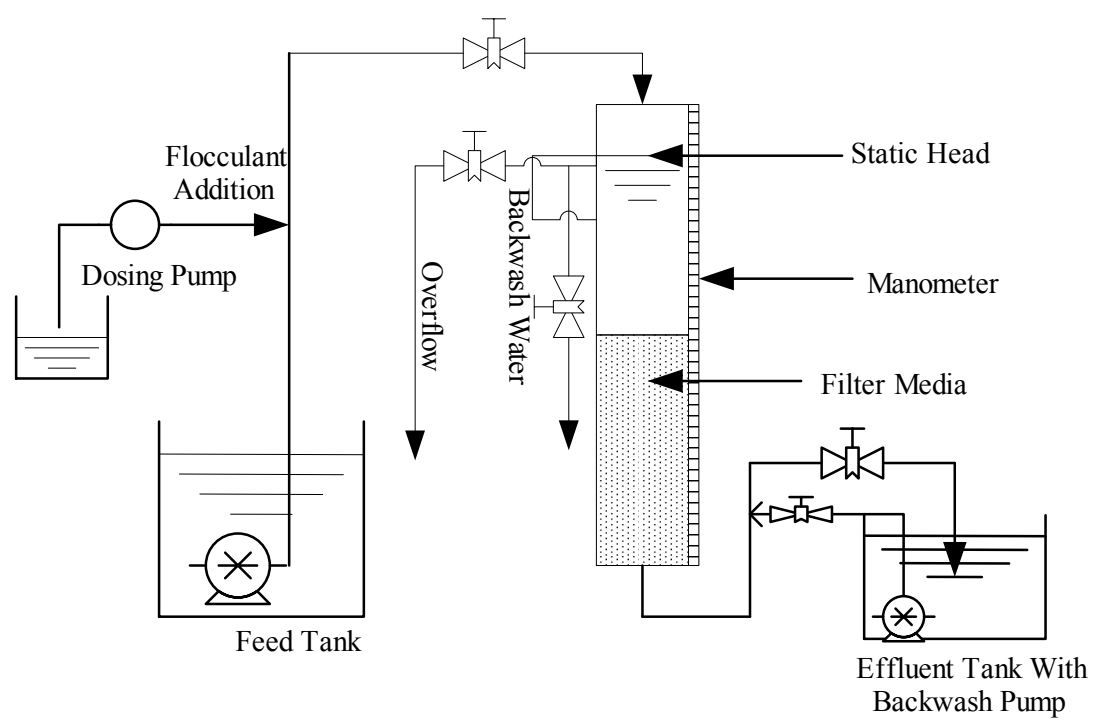

Fig. 1. Schematic of deep bed filtration systems.

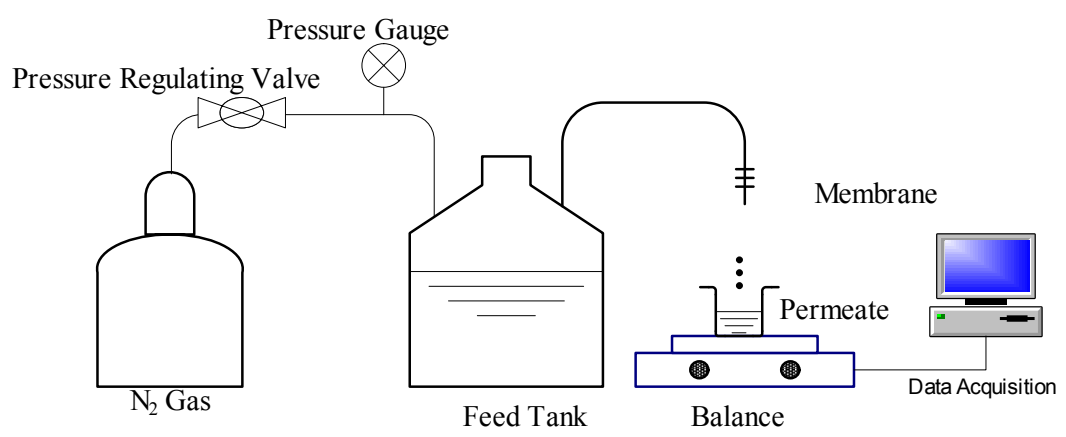

Fig. 2. MFI experimental set-ups.

Table 2

Physical properties of anthracite and sand

\begin{tabular}{lll}
\hline Parameter & Anthracite & Sand \\
\hline Effective size, mm & $1.0-1.1$ & $0.55-0.65$ \\
Uniformity coefficient & 1.30 & $<1.5$ \\
Acid solubility & $1 \%$ & $<2 \%$ \\
Specific gravity & 1.45 & 2.65 \\
Bulk density, $\mathrm{kg} / \mathrm{m}^{3}$ & $660-720$ & 1500 \\
\hline
\end{tabular}

to obtain the data on the residual fouling. The details of UF membrane are given in Table 3 . The raw stormwater and pre-filtered water were pressurized at $200 \mathrm{kPa}$ using $\mathrm{N}_{2}$ gas. The MFI value is the slope of plot of $t / V$ vs. $V$ of Eq. (1) $[8,9]$.

$$
\begin{aligned}
& \frac{t}{V}=\frac{\eta R_{m}}{\Delta P A}+\frac{\eta \alpha C_{b}}{2 \Delta P A^{2}} V \\
& \stackrel{\text { Slope (MFI) }}{\longrightarrow}
\end{aligned}
$$

Table 3

Characteristics of the UF membrane used

\begin{tabular}{ll}
\hline Item & Characteristics \\
\hline Code & NTR 7410 \\
Material & Sulfonated polysulfones \\
Molecular weight cut off, Da & 17500 \\
Contact angle, & 60 \\
Zeta potential at $\mathrm{pH} 7, \mathrm{mV}$ & -50.45 \\
$\begin{array}{l}\text { Pure water permeability at } 300 \\
\mathrm{kPa}, \mathrm{L} / \mathrm{m}^{2} \mathrm{~h}\end{array}$ & 125.5 \\
$\mathrm{Rm}\left(\mathrm{membrane} \mathrm{resistance,}^{\circ}\right.$ & 14.1 \\
$\times 10^{12} \mathrm{~m}^{-1}$ & \\
\hline
\end{tabular}

where $V$ - total permeate volume (1), $R_{m}-$ membrane resistance $(1 / \mathrm{m}), t-$ filtration time $(\mathrm{s}), \Delta P-$ applied trans-membrane pressure $(\mathrm{Pa}), \eta-$ water viscosity at $20^{\circ} \mathrm{C}, \alpha-$ specific resistance of the cake deposited. $C_{\mathrm{b}}$ - concentration of particles in feed water $(\mathrm{mg} / \mathrm{l}), A-$ membrane surface area $\left(\mathrm{m}^{2}\right)$. 
The $t / V$ VS. $V$ plot normally shows three phases of fouling, namely (i) blocking filtration, (ii) cake filtration without compression and (iii) cake plugging and/or cake compression. The first sharp increase in slope is attributed to membrane pore blocking followed by cake filtration, which is the linear region of the curve. The MFI is defined as the gradient $(\tan \theta)$ of this linear region of the $t / V$ vs. $V$ plot normalized to standard reference values of 2 bar $(207 \pm 3 \mathrm{kPa})$ trans-membrane pressure.

\subsection{Membrane filtration}

The schematic diagram of the membrane filtration system is shown in Fig. 3. Short term (90 min) experiments were conducted with stormwater pre-treated with contact flocculation-filtration. The hollow fibre membranes $\left(\right.$ Cleanfil $\left.^{\circledR}-S\right)$ were vertically submerged directly into a 10 L reactor (Fig. 3). Properties of the hollow fibre membrane used are given in Table 4. Constant flux experiments were conducted and the transmembrane pressure (TMP) was measured by a pressure sensor.

Total organic carbon (TOC) concentration of raw water

Table 4

Characteristics of the hollow fibre membrane used

\begin{tabular}{ll}
\hline Item & Characteristics \\
\hline Material & Polysulfone \\
Nominal pore size, $\mu \mathrm{m}$ & 0.3 \\
Outer diameter, $\mathrm{mm}$ & 1.9 \\
Inner diameter, $\mathrm{mm}$ & 0.7 \\
No. of fiber & 40 \\
Length of fiber, $\mathrm{mm}$ & 400 \\
Surface area, $\mathrm{m}^{2}$ & 0.1 \\
Mechanical strength, $\mathrm{kg}_{\mathrm{f}} / \mathrm{fil}$ & $>20$ \\
Membrane manufacturer & Kolon Industries, Inc., Korea \\
\hline
\end{tabular}

and treated water was measured by using the Multi N/C 2000 analyzer (Analytik Jena AG).

Detailed laboratory analyses were carried out to determine individual pollutants. The pollutants analysed were heavy metals - aluminium, arsenic, cadmium, chromium, copper, iron, lead, manganese, mercury, nickel, selenium, silver and zinc; mineral salts - calcium, magnesium, chloride, potassium, sodium and sulphate. Other parameters measured were nitrate and nitrite, $\mathrm{pH}$, ammonia, orthophosphate, conductivity, water hardness, turbidity, total suspended solids, total dissolved salts and bicarbonate. The water quality parameter measuring methods are given Table 5 .

\section{Results and discussion}

\subsection{Deep bed filter}

\subsubsection{Headloss development}

Fig. 4 shows the headloss development profile of the deep bed filter as a function of time. A study of the effect on flocculant mixing time showed that mixing time had very little effect on headloss development within the range of values used $(1,1.2,1.5$ and $3 \mathrm{~s})$. Here flocculant mixing time is the time for the flocculants to mix with the water prior to its entry into the filter (for uniform dispersal of flocculants with water). Normally it should be less than 10-30 s, which is also the case in our study. When the mixing time was $3 \mathrm{~s}$, the headloss development increased slightly (Fig. 4a). Thus in subsequent experiment a pre-mixing time of $3 \mathrm{~s}$ was used.

The use of flocculant increases the headloss development. It is found that the headloss development with a $15 \mathrm{mg} / \mathrm{L}$ coagulant dose operating at a filtration velocity of $5 \mathrm{~m} / \mathrm{h}$ was $74 \mathrm{~cm}$ after $5 \mathrm{~h}$ of filter run (Fig. 4c). A higher filtration velocity $(15 \mathrm{~m} / \mathrm{h})$ showed a higher headloss development compare with filtration velocities of 5 and

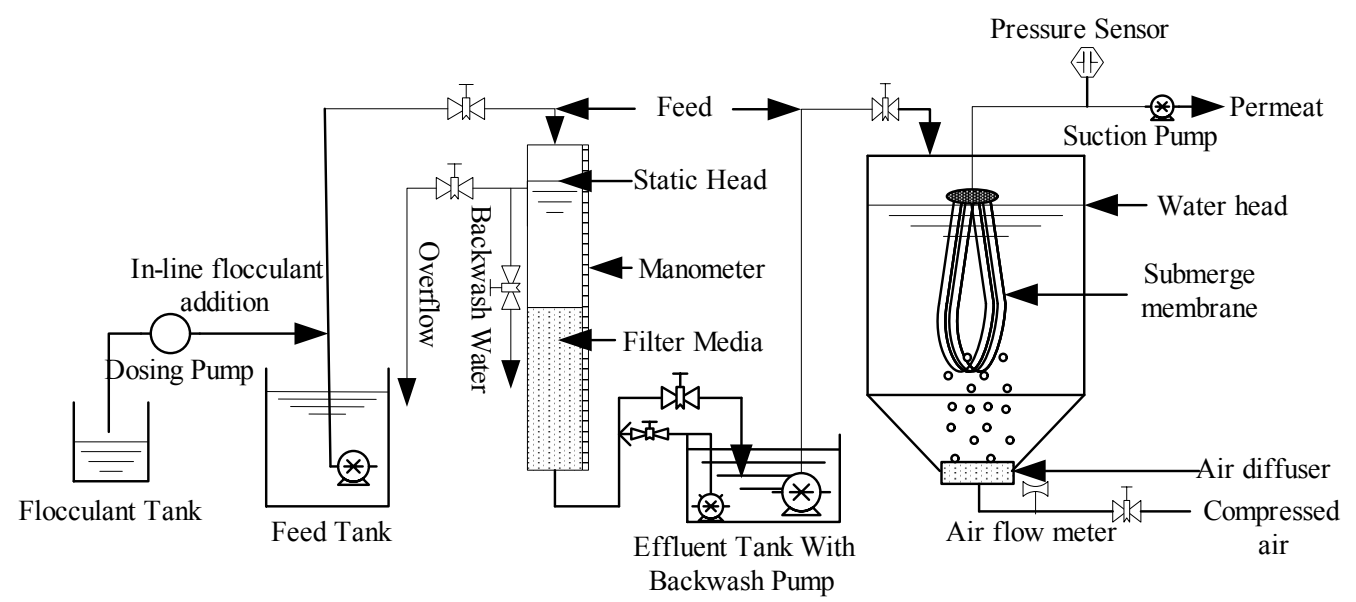

Fig. 3. Schematic diagram of the hollow fibre submerge membrane filtration system. 
Table 5

Water quality parameters and measurement methods

\begin{tabular}{|c|c|}
\hline Parameter & Measurement method \\
\hline $\begin{array}{l}\text { Heavy metals (aluminium, arsenic, cadmium, chro- } \\
\text { mium, copper, iron, lead, manganese, mercury, nickel, } \\
\text { selenium, silver and zinc) }\end{array}$ & $\begin{array}{l}\text { APHA } 3120 \text { ICPMS - Inductively coupled plasma - Mass } \\
\text { spectrometry }\end{array}$ \\
\hline Chloride & APHA 4500-CL - G - Mercuric Thiocyanate flow injection analysis \\
\hline Nitrate & APHA $4500 \mathrm{NO}_{3}^{-}-\mathrm{F}-$ Automated cadmium reduction method \\
\hline Nitrite & APHA $4500 \mathrm{NO}_{2}^{-}-\mathrm{B}$ - Colorimetric method \\
\hline $\begin{array}{l}\text { Mineral salts (calcium, magnesium, potassium, sodium } \\
\text { and sulphate) }\end{array}$ & $\begin{array}{l}\text { APHA } 3120 \text { ICPOES - Inductively coupled Plasma - Optical emis- } \\
\text { sion spectrometry }\end{array}$ \\
\hline $\mathrm{pH}$ & APHA 4500-H+ - Electronic method \\
\hline Ammonia & APHA $4500 \mathrm{NH}_{3}^{-} \mathrm{H}-$ Flow injection analysis \\
\hline Orthophosphate & APHA 4500 P-G - Flow injection analysis for orthophosphate \\
\hline Conductivity & APHA 2510-B - Laboratory method \\
\hline Water hardness & Calcium and magnesium calculation \\
\hline Turbidity & APHA 2130 - Nephelometric method \\
\hline Total suspended solids & $\begin{array}{l}\text { GFC equiv. filter - APHA } 2540-\mathrm{D}-\text { Total suspended solids dried } \\
\text { at } 103-105^{\circ} \mathrm{C}\end{array}$ \\
\hline Total dissolved salts & Calculation using EC $\times 680$ \\
\hline Bicarbonates & Total alkalinity - APHA 2320 - Titration method \\
\hline
\end{tabular}
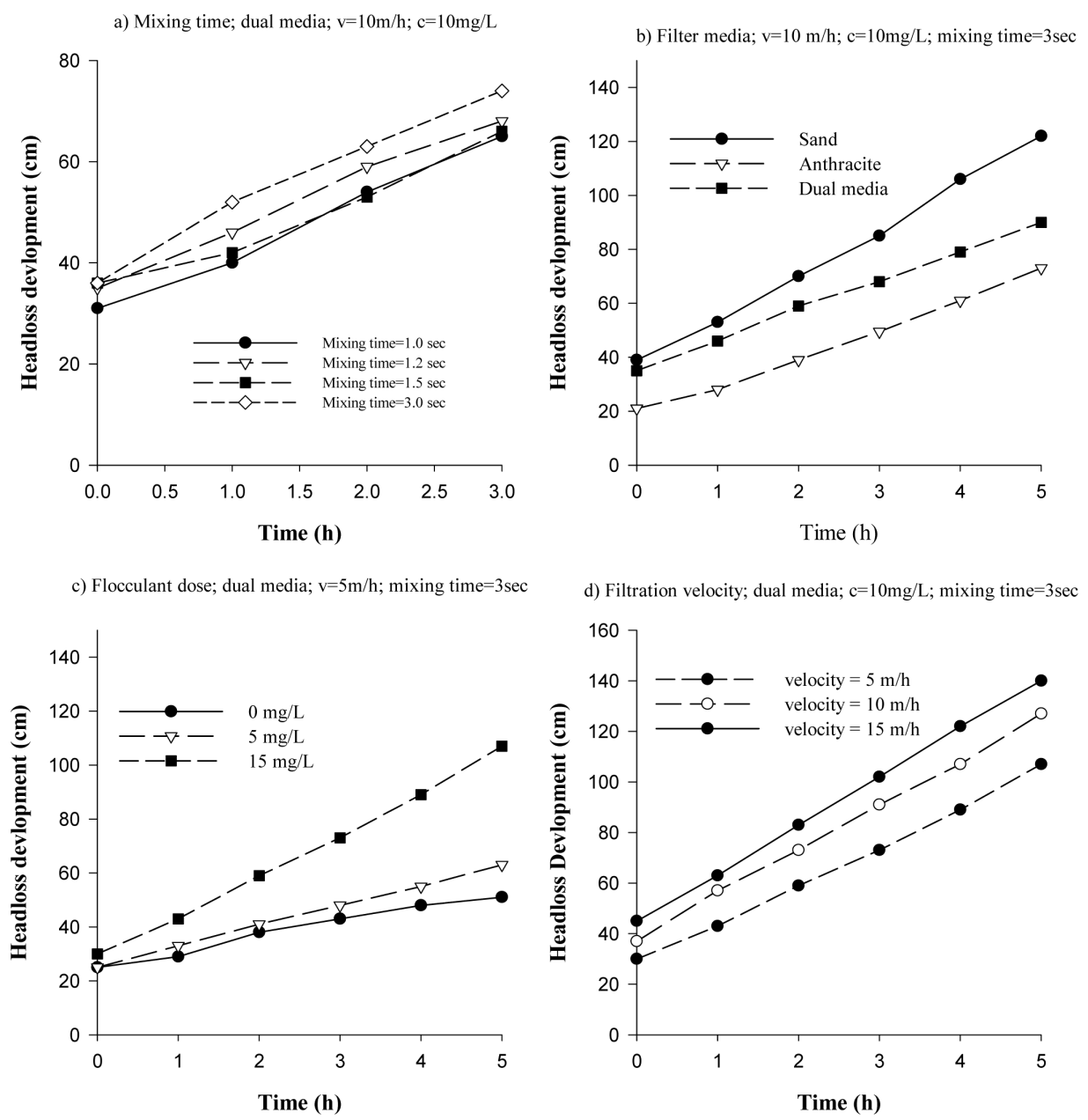

Fig. 4. Effect of filter operating parameter on headloss development ( $\mathrm{v}=$ velocity; $\mathrm{c}=$ flocculant dose). 
$10 \mathrm{~m} / \mathrm{h}$ (Fig. 4d). The filter media had a significant effect on headloss development and it is found that a finer filter media of sand had a higher headloss development of 83 cm compared with coarser media filters of anthracite and dual media which had a higher headloss development of 52 and $65 \mathrm{~cm}$ respectively (Fig. 4b).

\subsubsection{Turbidity removal}

Fig. 5 presents the filter removal efficiency for turbidity under different operation condition. Raw water turbidity was in the range of 5-45 NTU. After pre-treatment with in-line flocculation-filtration the turbidity reduced to 0.34-1.67 NTU. Experiments conducted on the effect of various mixing time $(1,1.2,1.5$ and $3 \mathrm{~s})$ on turbidity removal showed that mixing time had almost no effect (Fig. 5a). The use of flocculant increased turbidity removal efficiency with a flocculant dose of $15 \mathrm{mg} / \mathrm{L}$ showing the best removal (93-95\%) (Fig. 5d).

The effect of filtration velocity $(5,10$ and $15 \mathrm{~m} / \mathrm{h})$ showed that a lower filtration velocity $(5 \mathrm{~m} / \mathrm{h})$ had a moderately good removal of turbidity (Fig. 5c). A comparison was made between sand, anthracite and dual media filters operated at a filtration velocity of $10 \mathrm{~m} / \mathrm{h}$ with in-line flocculation of $10 \mathrm{mg} / \mathrm{L} \mathrm{FeCl}_{3}$. The dual media resulted in a better turbidity removal efficiency (90-95\%) than the single media filters (65-90\%) (Fig. 5b).

\subsubsection{Total organic carbon (TOC) removal efficiency}

The TOC removal efficiency by in-line flocculationfiltration is presented in Table 6. TOC removal efficiency increased slightly (from $30 \%$ to $36 \%$ ) when the flocculant mixing time increased from $1.0 \mathrm{~s}$ to $3.0 \mathrm{~s}$ (Table 6). It is found that the TOC removal efficiency increased with the flocculant dose. The best removal efficiency of TOC (up to $50 \%$ ) was achieved when the flocculant dose increased from 5 to $15 \mathrm{mg} / \mathrm{L}$ (Table 6) for dual media filtration systems operated a filtration velocity of $5 \mathrm{~m} / \mathrm{h}$.
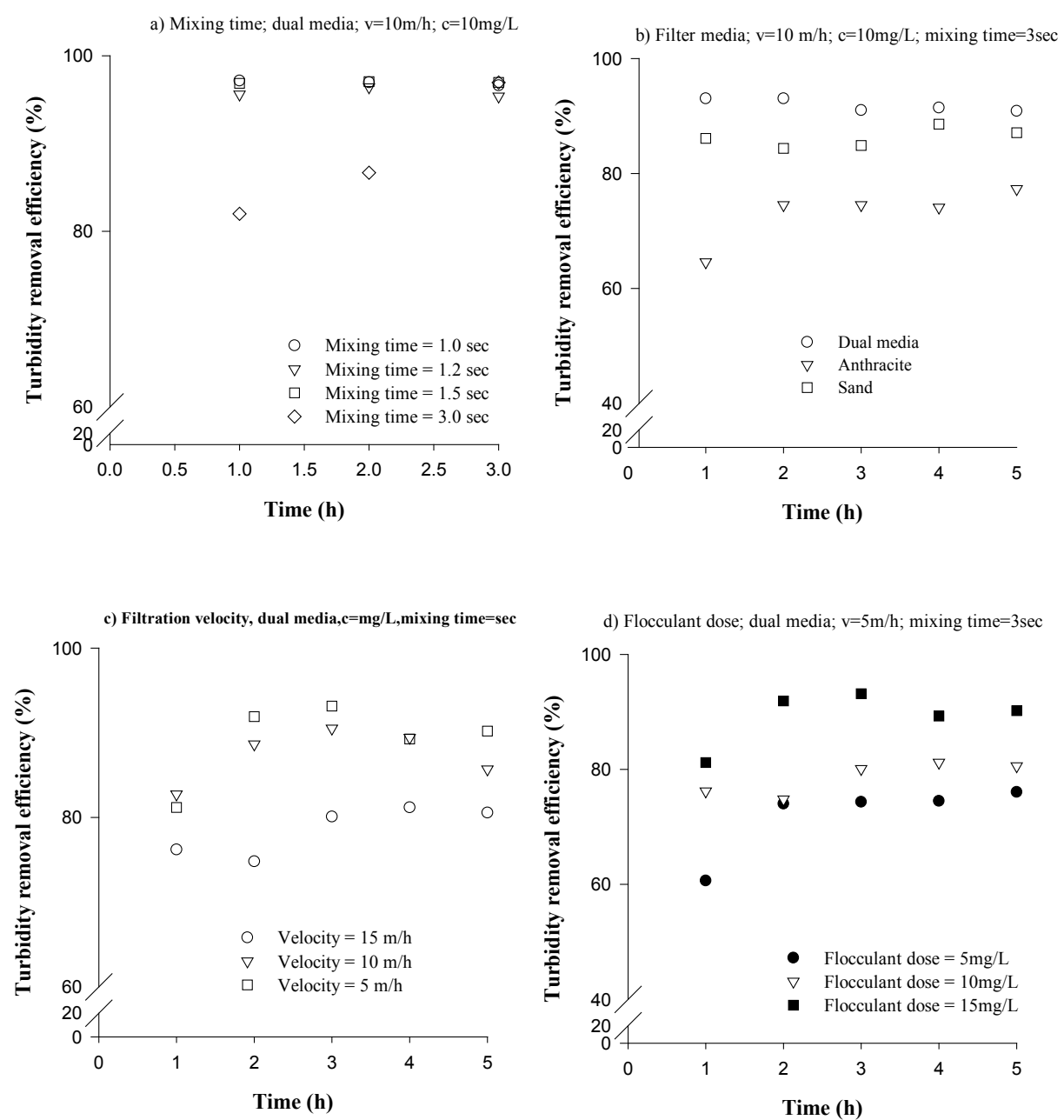

Fig. 5. Effect of filter operating parameter on turbidity removal efficiency (raw water turbidity $=2.5-45 \mathrm{NTU} ; \mathrm{v}=\mathrm{velocity} ; \mathrm{c}=$ flocculant dose). 
Table 6

TOC removal efficiency with and without flocculation (raw water TOC 4.25-8.96 mg/L)

\begin{tabular}{lllll}
\hline Media & $\begin{array}{l}\text { Velocity } \\
(\mathrm{m} / \mathrm{h})\end{array}$ & $\begin{array}{l}\text { Mixing time } \\
(\mathrm{s})\end{array}$ & $\begin{array}{l}\text { Flocculant dose } \\
(\mathrm{mg} / \mathrm{l})\end{array}$ & $\begin{array}{l}\text { TOC removal efficiency } \\
(\%)\end{array}$ \\
\hline Dual media (sand + anthracite) & 10 & 1 & 10 & 31.22 \\
& 10 & 1.2 & 10 & 31.21 \\
& 10 & 1.5 & 10 & 30.60 \\
Dual media (sand + anthracite) & 10 & 3 & 10 & 36.30 \\
& 5 & - & 0 & 12.66 \\
& 5 & 3 & 5 & 19.01 \\
& 10 & 3 & 5 & 16.38 \\
& 10 & 3 & 10 & 31.22 \\
Anthracite & 5 & 3 & 15 & 50.78 \\
& 10 & 3 & 15 & 48.73 \\
& 15 & 3 & 10 & 29.87 \\
Sand & 10 & 3 & 5 & 11.21 \\
& 10 & 3 & 15 & 34.73 \\
& 10 & 3 & 10 & 28.99 \\
\end{tabular}

3.2. Molecular weight distribution (MWD) of organic compounds

The molecular weight of organic substances was measured using the high-performance liquid chromatography (HPLC) in order to investigate the removal of organic matter of different molecular weight ranges. The results are presented in Fig. 6. It was found that both filters studied under different condition were able to remove large molecules within the MW ranges of 29500-700 Da when $\mathrm{FeCl}_{3}$ was used as flocculant. The removal measured in terms of UV absorbance intensity was higher for larger

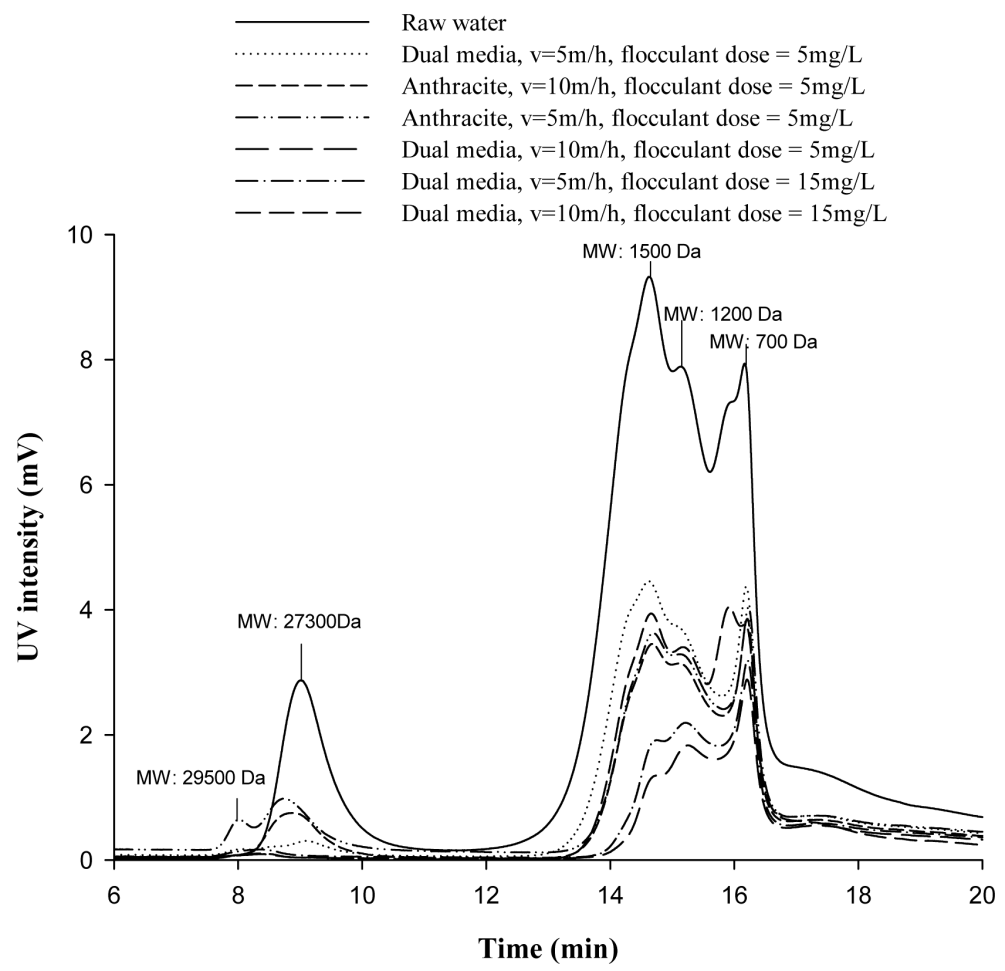

Fig. 6. Molecular weight distributions of organic matters in stormwater before and after treatment. 
doses of $\mathrm{FeCl}_{3}$. The most significant decrease in the intensity of the absorbance peaks was observed with dual media filter operated at 5 and $10 \mathrm{~m} / \mathrm{h}$ filtration velocity with a $\mathrm{FeCl}_{3}$ dose of $15 \mathrm{mg} / \mathrm{L}$ (Fig. 6).

\subsection{Modified fouling index (MFI)}

The efficiency of the filters used under different operation conditions was assessed in terms of modified fouling index (MFI). After filtration with and without flocculation the MFI value reduced from between 750$950 \mathrm{~s} / \mathrm{L}^{2}$ to $15-20 \mathrm{~s} / \mathrm{L}^{2}$ and $215 \mathrm{~s} / \mathrm{L}^{2}$ (Table 7). Dual media and anthracite filters operated at filtration velocities of 10 and $5 \mathrm{~m} / \mathrm{h}$ with a $\mathrm{FeCl}_{3}$ dose of $15 \mathrm{mg} / \mathrm{L}$ gave superior reduction of MFI of $13 \mathrm{~s} / \mathrm{L}^{2}$ and $15 \mathrm{~s} / \mathrm{L}^{2}$ respectively. The effect of mixing time on MFI values is shown in Table 7. There was a slight reduction in MFI with longer (3.0 s) mixing time. UF-MFI experiments were conducted to evaluate the fouling rate of the UF membrane after filtration. It was found that all filters showed a lower rate of fouling of the UF membrane, which reduced UF-MFI values from $23400 \mathrm{~s} / \mathrm{L}^{2}$ (for raw water) to $3500-3920 \mathrm{~s} / \mathrm{L}^{2}$ (Table 8). The fouling was mainly due to suspended solids (of small size), colloidal particles and dissolved organic matter. These particles are agglomerated effectively by the addition of flocculants then removed by the filtration.

\subsection{Water hardness, $\mathrm{pH}$ conductivity and colour removal efficiency}

After filtration the water hardness was almost the same as raw water. Similarly the amount of carbonate and bicarbonate did not change. The bicarbonate, carbonate and water hardness with different filtration at different velocity and flocculant doses were in the range of 10-95 mg/L CaCO ${ }_{3}$ equivalent, 0-20, 30-95 mg/ $\mathrm{L} \mathrm{CaCO}_{3}$ equivalent and 22-143, 30-95 mg/L CaCO 3 equivalent respectively.

The $\mathrm{pH}$ values were 6.55-7.45 after filtration for all conditions, which imply that the filtered water was almost neutral. In terms of colour removal, it can be seen that removal efficiency for colour increased with the coagulant dose (from $10 \%$ to $99 \%$ ). It is found that the anthracite filter with $5 \mathrm{mg} / \mathrm{L}$ coagulant dose could not effectively remove colour $(10 \%)$. Dual media filters with a $15 \mathrm{mg} / \mathrm{L}$ coagulant dose operated at velocities of 5 and $10 \mathrm{~m} / \mathrm{h}$ effectively removed colour (about $80-99 \%$ ) as did the anthracite filters operated at $10 \mathrm{~m} / \mathrm{h}$ velocity with a $15 \mathrm{mg} / \mathrm{L}$ coagulant dose ( $99 \%$ ). The use of $15 \mathrm{mg} / \mathrm{L}$ coagulant dose improves colour removal efficiency. The conductivity of effluents was within the range of $0.126-1.05 \mathrm{dS} / \mathrm{m}$ for all operating condition.

\subsection{Nutrients removal efficiency}

In general, for in-line flocculation followed by either single filtration or dual media filtration, the concentra-
Table 7

MFI value with and without flocculation (raw water MFI 750-950 s/L²)

\begin{tabular}{llllc}
\hline Media & $\begin{array}{l}\text { Velocity } \\
(\mathrm{m} / \mathrm{h})\end{array}$ & $\begin{array}{l}\text { Mixing } \\
\text { time }(\mathrm{s})\end{array}$ & $\begin{array}{l}\text { Coagulant } \\
\text { dose }(\mathrm{mg} / \mathrm{l})\end{array}$ & $\begin{array}{l}\text { MFI } \\
\left(\mathrm{s} / \mathrm{L}^{2}\right)\end{array}$ \\
\hline Dual media & 10 & 1 & 10 & 61 \\
(sand + & 10 & 1.2 & 10 & 25 \\
anthracite) & 10 & 1.5 & 10 & 51 \\
& 10 & 3 & 10 & 42 \\
Dual media & 5 & - & 0 & 215 \\
(sand + & 10 & 3 & 10 & 25 \\
anthracite) & 5 & 3 & 15 & 15 \\
& 10 & 3 & 15 & 20 \\
& 15 & 3 & 10 & 20 \\
Anthracite & 10 & 3 & 5 & 340 \\
& 10 & 3 & 15 & 13 \\
Sand & 10 & 3 & 10 & 225 \\
\hline
\end{tabular}

Table 8

Effect of pre-treatment on UF-MFI value (raw water UF-MFI $23400 \mathrm{~s} / \mathrm{L}^{2}$ )

\begin{tabular}{llll}
\hline Media & $\begin{array}{l}\text { Velocity } \\
(\mathrm{m} / \mathrm{h})\end{array}$ & $\begin{array}{l}\text { Coagulant } \\
\text { dose }(\mathrm{mg} / \mathrm{l})\end{array}$ & MFI (s/L²) \\
\hline Dual media & 10 & 10 & 3610 \\
(sand + anthracite) & 15 & 10 & 3920 \\
Anthracite & 10 & 10 & 3760 \\
Sand & 10 & 10 & 3550 \\
\hline
\end{tabular}

tion of $\mathrm{NO}_{x^{\prime}}$ nitrate and nitrite reduced from 0.38-8.1, $0.38-7.9 \mathrm{mg} / \mathrm{L} \mathrm{N}, 0.004-0.97 \mathrm{mg} / \mathrm{L} \mathrm{N}$, to $0.006-4.18$, $0.005-4.18 \mathrm{mg} / \mathrm{L} \mathrm{N}$, and $0.005-0.6 \mathrm{mg} / \mathrm{L} \mathrm{N}$ respectively. The removal efficiency of phosphorus was relatively high which reduced from $0.02-0.026$ to $0.005-0.012 \mathrm{mg} / \mathrm{L} \mathrm{P}$ under most of the operational condition.

\subsection{Heavy metal removal efficiency}

Table 1 shows the low influent concentrations of cadmium $(0.001 \mathrm{mg} / \mathrm{L})$, chromium $(0.002 \mathrm{mg} / \mathrm{L})$, nickel $(0.002-0.10 \mathrm{mg} / \mathrm{L})$, lead $(0.019-0.022 \mathrm{mg} / \mathrm{L})$ and iron $(0.53-2.550 \mathrm{mg} / \mathrm{L})$. The heavy metal removal efficiency varied with the initial concentration of pollutants and particulate matter in the influent. In this study most of the filters showed almost similar performance in heavy metal removal efficiency. For example, manganese removal was between $40-53.7 \%$. Iron, zinc and aluminium were removed at similar rates by deep bed filters. Lead, copper and cadmium removal by these filters was much lower ( $1-2 \%)$, and nickel removal was between $3-4 \%$. The low removal efficiency of these metals is due to their low concentration in the influent stormwater. 


\subsection{Submerged hollow fibre membrane as post treatment}

Fig. 7a shows the variation of trans-membrane pressure (TMP) for constant filtration flux using the stormwater with and without pre-treatment. The pre-treatment used was in-line flocculation-filtration with a $\mathrm{FeCl}_{3}$ dose of $10 \mathrm{mg} / \mathrm{L}$ and filtration velocity was $10 \mathrm{~m} / \mathrm{h}$. Without pre-treatment the TMP development was $0.8 \mathrm{kPa}$ during the experimental period. The pre-treatment reduce the pressure development significantly (to less than $0.1 \mathrm{kPa}$ ).

Membrane filtration without pre-treatment reduced the turbidity of stormwater from 25-35 NTU to less than 0.29 (i.e $98 \%$ removal). The pre-treatment slightly enhanced the removal of turbidity (to less than $0.2 \mathrm{NTU}$ ) (Fig. 7b).

Fig. 7c shows the TOC removal efficiency of the submerged hollow fibre membrane process. The TOC in the influent was about $5.25 \mathrm{mg} / \mathrm{L}$ and the average TOC removal by submerged membrane itself was only about $7 \%$. The microfiltration alone cannot remove the TOC due to its large pore size $(0.3 \mu \mathrm{m})$. The marginal removal is due to adsorption of organic on membrane. An in-line flocculation-filtration followed by hollow fibre membrane system improved the TOC removal efficiency from $7 \%$ to $40 \%$. In-line flocculation-filtration helped to remove larger molecules of organic compounds (Fig. 7d).

\subsection{Determination of critical flux}

The critical (sustainable) flux was measured by the flux-step method using the constant flux mode of operation. The filtration time was set at $90 \mathrm{~min}$ for each flux value and the flux was increased in increments of 2 $3 \mathrm{~L} / \mathrm{m}^{2}$.h from 5 to $20 \mathrm{~L} / \mathrm{m}^{2}$.h.
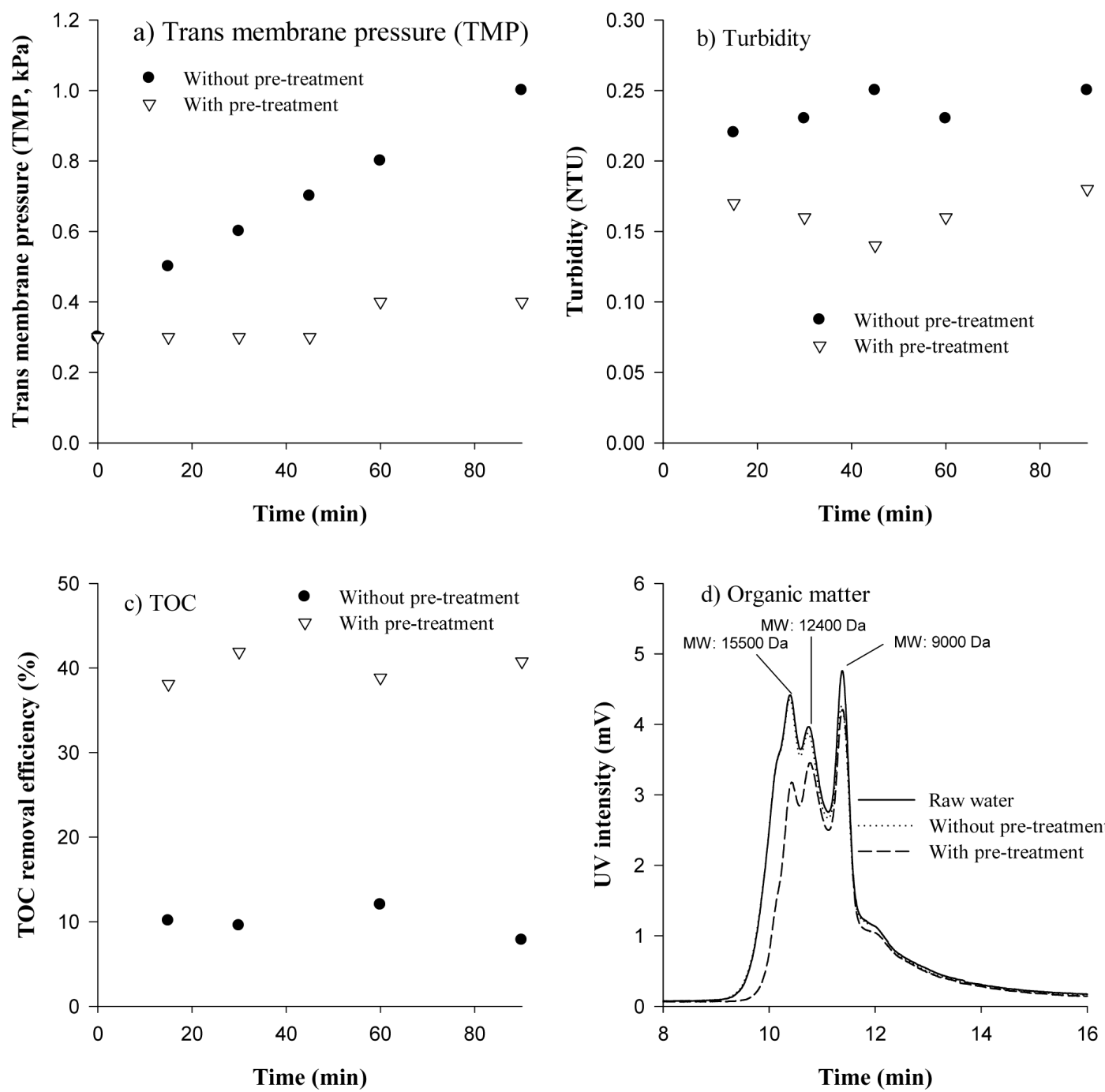

Fig. 7. Effect of pre-treatment of contact flocculation on submerged membrane reactor used as post treatment (dual media; deep bed filter velocity $=10 \mathrm{~m} / \mathrm{h}$; flocculant dose $=10 \mathrm{mg} / \mathrm{L}$; hollow fibre membrane area $=0.1 \mathrm{~m}^{2}$; flow rate $=5 \mathrm{~L} / \mathrm{m}^{2} . \mathrm{h}$; aeration rate $3.8 \mathrm{~m}^{3} / \mathrm{m}^{2}$ membrane area; raw water turbidity $25-35 \mathrm{NTU}$; turbidity after pre-treatment $=0.43-0.69$ NTU; raw water TOC $=5.25-6.25 \mathrm{mg} / \mathrm{L}$; TOC after pre-treatment $=2.21-2.93 \mathrm{mg} / \mathrm{L})$. 
In this series of experiments, the feed turbidity of pre-treated water was $0.49-0.89$ NTU and the normalize aeration rate was set at $3.8 \mathrm{~m}^{3} / \mathrm{m}^{2} . \mathrm{h}$ membrane area. The suction pressure remained constant for each flux up to a flux of $10 \mathrm{~L} / \mathrm{m}^{2}$.h. Beyond this flux, the suction pressure started to increase (Fig. 8). Thus, the critical (sustainable) flux for the pre-treated effluent was $10 \mathrm{~L} / \mathrm{m}^{2} . h$.

\subsection{Effect of aeration rate on critical flux}

Experiments were also conducted by various airs scouring to see whether there is any increase in critical flux with the increase in air scouring. Fig. 9 presents the TMP profile at a flux of $10 \mathrm{~L} / \mathrm{m}^{2} . \mathrm{h}$ for different aeration rates. It is found that the increase of aeration rates decreased the pressure development. With an aeration rate of $1.8 \mathrm{~m}^{3} / \mathrm{m}^{2} . \mathrm{h}$ (in terms of membrane area) the pressure development was $1.6 \mathrm{kPa}$ and for $2.7 \mathrm{~m}^{3} / \mathrm{m}^{2} . \mathrm{h}, 3.80 \mathrm{~m}^{3} / \mathrm{m}^{2} . \mathrm{h}$,
$4 \mathrm{~m}^{3} / \mathrm{m}^{2} . \mathrm{h}$ and $6 \mathrm{~m}^{3} / \mathrm{m}^{2} . h$ (in terms of membrane area) it was $1 \mathrm{kPa}, 0.2 \mathrm{kPa}, 0.3 \mathrm{kPa}$ and $0.2 \mathrm{kPa}$ respectively.

To study the effect of aeration rate on a possible increase in critical flux a study was conducted with a higher flux of $15 \mathrm{~L} / \mathrm{m}^{2} \mathrm{~h}$. From this study it is found that with higher aeration rates the pressure development is low. With an aeration rate of $3.8 \mathrm{~m}^{3} / \mathrm{m}^{2}$.h (in terms of membrane area) the TMP development was $3.5 \mathrm{kPa}$, whereas with an aeration rate of $6 \mathrm{~m}^{3} / \mathrm{m}^{2} . h$ (in terms of membrane area) the TMP development was $2.1 \mathrm{kPa}$. These results imply that sustainable flux cannot be significantly improved by providing higher air scour. This phenomenon can be explained by the important role in inducing a cross-flow effect that causes particle to be transported away from the membrane surface [10]. Thus, it is better to operate at sustainably higher flux with minimum possible air scour to reduce the TMP development.

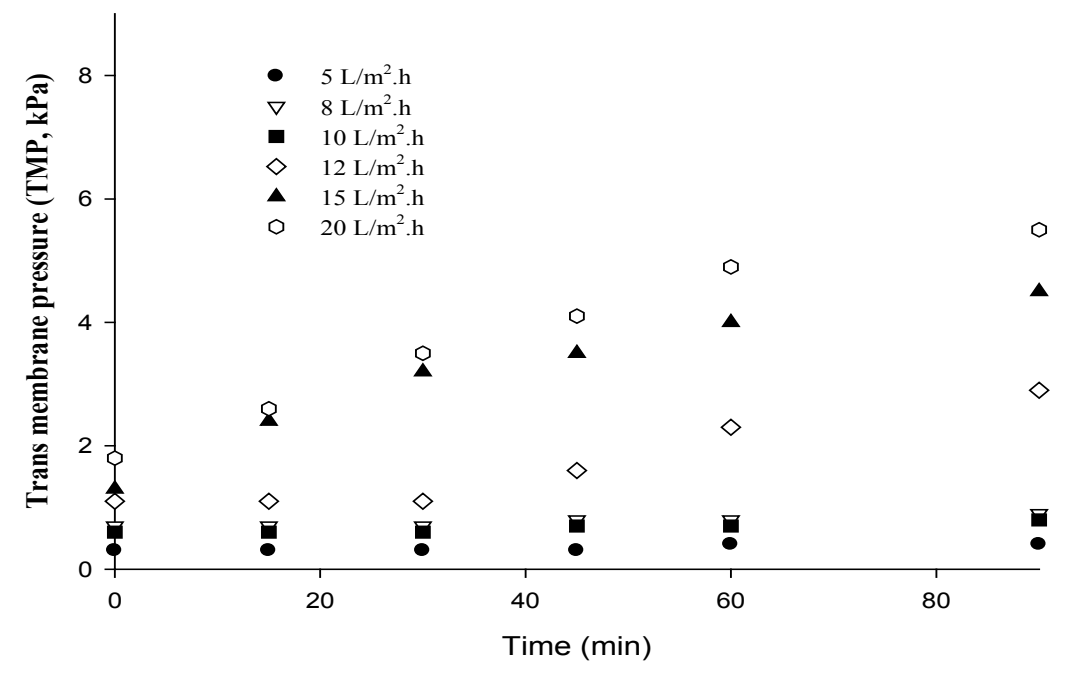

Fig. 8. Determination of critical flux of submerged membrane reactor using pre-treated water by flux-step method (feed turbidity $=0.43-0.69 \mathrm{NTU}$; aeration rate $=3.8 \mathrm{~m}^{3} / \mathrm{m}^{2}$ membrane area.h, membrane area $=0.1 \mathrm{~m}^{2}$ ).

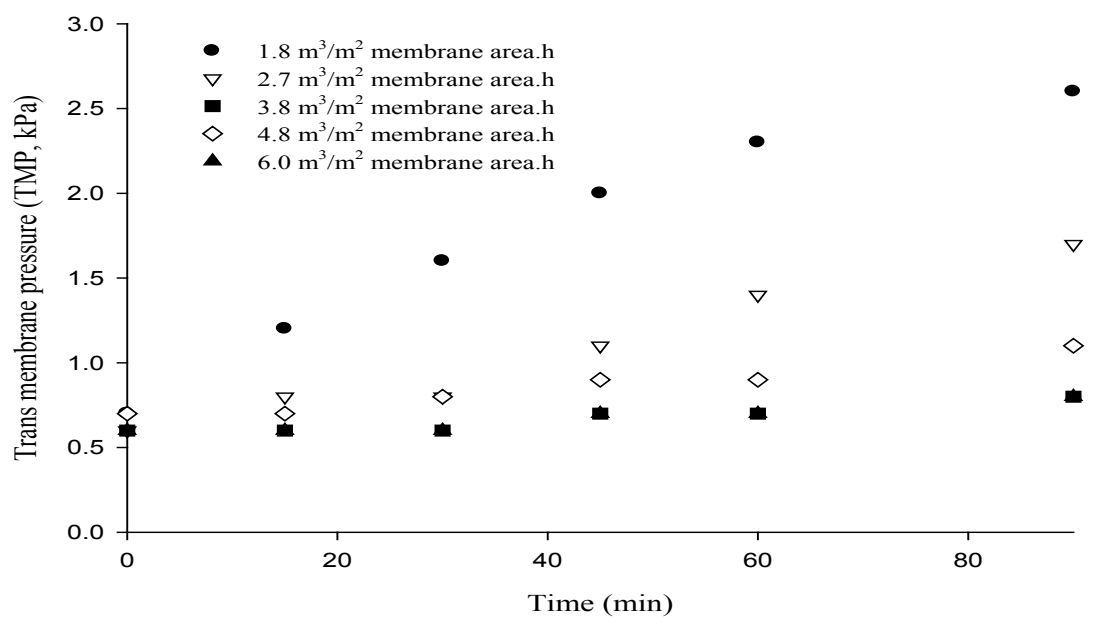

Fig. 9. Effect of aeration rate on critical flux (flow rate $=10 \mathrm{~L} / \mathrm{m}^{2} . \mathrm{h}$; feed turbidity $=0.43-0.69 \mathrm{NTU}$; membrane area $=0.1 \mathrm{~m}^{2}$ ). 


\section{Conclusions}

In this study, different filter systems that could be used for stormwater pollution control were tested. The main conclusions were:

- In-line flocculation and filtration systems showed a tendency of rapid hydraulic clogging resulting in a higher head loss development during the period of operation $(5 \mathrm{~h})$. Compared with sand filter, dual media and anthracite filter showed a lower headloss development.

- The removal efficiency of turbidity, suspended solids and TOC was found to increase with flocculant doses. Turbidity and suspended solids removal efficiency was high for all filtration systems (up to 95\%). However, dual media filters showed better removal efficiency for TOC (50\%). All filtration systems showed excellent colour removal efficiency ( $99 \%$ ) at $\mathrm{FeCl}_{3}$ dose of $15 \mathrm{mg} / \mathrm{L}$.

- After filtration with and without flocculation, the MFI value reduced from $750-950 \mathrm{~s} / \mathrm{L}^{2}$ to $15-20 \mathrm{~s} / \mathrm{L}^{2}$. All of these filters gave superior reduction of UF-MFI (from $23400 \mathrm{~s} / \mathrm{L}^{2}$ to $3500-3920 \mathrm{~s} / \mathrm{L}^{2}$ ).

- After filtration the amount of total coliform reduced significantly (up to $80 \%$ ). The removal was almost $99.99 \%$ after the microfiltration of submerged membrane as a post treatment. The removal efficiency of nitrogen was lower than phosphorus which was relatively good (up to $50 \%$ ).

- The removal efficiency of manganese, iron, aluminium and zinc was good and this was related to the mechanical filtration and reduction of suspension containing complexes of Fe, Mn, $\mathrm{Zn}$ and Al.

- The removal efficiency of heavy metals such as $\mathrm{Cd}, \mathrm{Pb}$, $\mathrm{Cr}$ and Ni removal efficiency was found to be very low for all filtration systems tested as their concentrations in the stormwater was low.

- Experiments with submerged hollow fibre membrane filtration showed that pre-treatment reduced fouling to the membrane resulting in a lower pressure development.

- Pre-treatment increased TOC removal efficiency of membrane filtration (from $7 \%$ to $40 \%$ ).
- The critical flux using pre-treated water was found to be $10 \mathrm{~L} / \mathrm{m}^{2} . \mathrm{h}$.

- Experiments testing the effect of aeration rate showed that beyond a certain value, the effect of aeration rate is negligible. At fluxes larger than the critical flux, an increase of aeration rate decreased pressure development.

\section{Symbols}

A - Membrane surface area, $\mathrm{m}^{2}$

$C_{b} \quad$ - Concentration of particles in feed water, $\mathrm{mg} / \mathrm{l}$

$R_{m}-$ Membrane resistance, $1 / \mathrm{m}$

$\Delta P-$ Applied trans-membrane pressure, $\mathrm{Pa}$

$t \quad-\quad$ Filtration time, $\mathrm{s}$

$V \quad-\quad$ Total permeate volume, 1

$\alpha-$ Specific resistance of the cake deposited

$\eta \quad$ Water viscosity at $20^{\circ} \mathrm{C}$

\section{Acknowledgements}

This work was funded by Australian Research Council Linkage Research Grant (LP0883485).

\section{References}

[1] E. Eriksson, A. Baun, L. Scholes, A. Ledin, S. Ahlman, M. Revitt, C. Noutsopoulos and P.S. Mikkelsen, Sci. Total Environ., 383 (2007) 41-51.

[2] G. Nogaro, F. Mermillod-Blondin, B. Montuelle, J.Boisson, M. Lafont, B. Volat and J. Gibert, Chemosphere, 70 (2007) 315-328.

[3] H.B. Dharmappa, J. Verink, O. Fujiwara and S. Vigneswaran, War. Res. 26(10) (1992) 1307-1318.

[4] S. Vigneswaran, J. Songchang and J.G. Janssens, Wat. Res., 24 7(1990) 927-930.

[5] A.G. Fane, S. Chang and E. Chardon, Desalination, 146 (2002) 231-236.

[6] J.C. Schippers and J. Verdouw, Desalination, 32 (1980) 131-148.

[7] J.C. Schippers, H.C. Folmer, J. Verdouw and. H.J. Scheerman, Desalination, 56 (1985) 109-119.

[8] S.F.E. Boerlage, M.D. Kennedy, M.P. Aniye, E.M. Abogrean, G. Galjaard and J.C. Schippers, Desalination, 118 (1998) 131-142.

[9] S.F.E. Boerlage, M.D. Kennedy, A.C. Paul, Bonne, G. Galjaard and J.C. Schippers, Desalination, 113 (1997) 231-233.

[10] J. Kim and F.A. Di Giano, J. Membr. Sci., 280 (2006) 752-761. 